\title{
The emergence of text-graphics conventions in a medical research journal: The Lancet 1823-2015
}

L'émergence de conventions texte-image dans une revue médicale, The Lancet 1823-2015

\section{Elizabeth Rowley-Jolivet}

\section{(2) OpenEdition}

\section{Journals}

Electronic version

URL: http://journals.openedition.org/asp/5107

DOI: $10.4000 / a s p .5107$

ISSN: 2108-6354

\section{Publisher}

Groupe d'étude et de recherche en anglais de spécialité

\section{Printed version}

Date of publication: 1 March 2018

Number of pages: 5-24

ISSN: 1246-8185

\section{Electronic reference}

Elizabeth Rowley-Jolivet, « The emergence of text-graphics conventions in a medical research journal: The Lancet 1823-2015 », ASp [Online], 73 | 2018, Online since 01 March 2019, connection on 04

November 2020. URL : http://journals.openedition.org/asp/5107 ; DOI : https://doi.org/10.4000/asp. 5107

This text was automatically generated on 4 November 2020.

Tous droits réservés 


\section{The emergence of text-graphics conventions in a medical research journal: The Lancet 1823-2015}

L'émergence de conventions texte-image dans une revue médicale, The Lancet 1823-2015

Elizabeth Rowley-Jolivet

\section{Introduction}

1 The literature on the growth of the scientific research article is vast, and several booklength studies have been devoted to its progressive development from the early epistolary communications in the $17^{\text {th }}$ century to the present (Banks 2008; Bazerman 1988; Gross et al. 2002; Halliday \& Martin 1993; Swales 1990, to mention but a few). The main focus of these investigations has been the emergence and conventionalization of the linguistic and rhetorical features of research articles, such as the IMRaD structure, or the construal of scientific research in specific phraseologies, terminologies and linguistic choices. They have provided us with a very rich and detailed picture of how the argument structures and language evolved in response to the evolution of science itself. There has been far less work, however, on the evolution of the conventions governing the interaction between the text and the non-linguistic elements in the research article, despite the widely recognized fact that specialized discourse makes meaning not just through language but through other semiotics (Lemke 1998). Indeed, as argued by Gross et al. (2002) and by Gross and Harmon (2013), this visual-verbal interaction is a defining feature of the modern research article, which can therefore not be approached or understood by considering the text alone:

[...] it is the interaction of visual and verbal texts, an interaction enabled and facilitated by devices of style and presentation, that constitutes the heart of scientific argumentative practices at the end of the twentieth century. (Gross et al. 2002: 213, my italics) 
[...] scientific communication is a consequence of the interaction between words and images. (Gross \& Harmon 2013: Chapter 1)

The present study focuses specifically on some of these presentational devices in order to trace the gradual emergence of the conventions governing the interaction between non-textual elements such as drawings, photographs, tables, graphs and schematics called 'graphics' hereafter for simplicity's sake - and the text in a medical journal. The need for explicit codification and rules to organize their juxtaposition and integration is in fact a fairly recent development in the history of the research article, dating roughly from the second half of the twentieth century. As pointed out by Gross et al. (2002: 162), despite some sporadic efforts at standardization in the first half of the $20^{\text {th }}$ century, and which mainly concerned the overall structure of articles rather than details of presentation, it was not until the 1950s, under pressure from the institutions and gatekeepers of science (scholarly societies, editorial boards of journals), that discipline-specific style manuals were published (in physics in 1951, biology in 1960, medicine in 1964, chemistry in 1967). Nowadays, as is well-known, highly detailed and constraining instructions for the presentation of data and text and their interaction have to be followed by all authors when submitting their manuscripts for publication. The Lancet, for example, subscribes to the recommendations of the ICMJE (International Committee of Medical Journal Editors), whose website specifies how the different types of medical articles should be organized and presented. ${ }^{1}$ Before the establishment of these explicit guidelines, text-graphics conventions and interaction appear to have evolved in a sporadic, unsystematic and spontaneous fashion - even if, with hindsight, one can discern trends at work - though not haphazardly. Indeed, I will argue that the evolution of these conventions parallels changes in the approach and knowledge of the discipline and therefore reflects, on a par with the development of the IMRaD structure (Swales 1990) or of scientific language (Banks 2008), the close relationship between semiotic resources and disciplinary context.

3 As a useful starting-point from which to trace the emergence of these conventions, we can take modern text-graphics conventions in scientific research articles. Briefly summarized, these are as follows: each graphic element is given its own textual space, clearly separated from the verbal text; it has a title and is numbered (Table I, Fig. 2, etc.); its different components are clearly labelled (headings of columns and rows in tables, axes and lines on graphs, labels or a key on schematics); it has an explanatory caption if further information is necessary to understand the content of the graphic; it is always referred to by name and number in the accompanying text (e.g. see Fig.1). It is these features that will be examined here over the last two centuries, from the founding of the first English medical journal, The Lancet, in 1823 up to the present.

4 This "master finding system" (Gross et al. 2002: 128) allows readers of the modern research article not only to easily locate and link up the graphics with the relevant parts of the text, it also enables a non-linear reading strategy. As shown by Bazerman's (1985) study of physicists, expert readers use selective, non-sequential reading strategies to spot the newsworthy information, a strategy greatly facilitated by the fact that the graphics, which generally contain the 'news', are sufficiently informative and have acquired enough autonomy from the text to be read by themselves (Bazerman 1988). In addition to tracing the emergence of the conventions themselves, this study will therefore also address the question of the autonomy of these non-textual elements with respect to the text, and track changes in the type of reading strategy favored at different periods. In the last few decades, for instance, a major development has been 
the migration of documents to the web and hypertextuality, which have resulted in text nowadays being broken up into modules or small chunks, generating a 'navigating' mode of reading. A diachronic approach allows one to put these recent developments into perspective and better understand their filiation with the changes that have gradually taken place over the centuries.

One of the few longitudinal studies to investigate this type of feature in scientific articles is Gross et al. (2002), covering over three centuries and three languages (English, French and German). In addition to analyzing style (syntax and lexis) and argument structure - aspects not addressed in the present study - they also looked at presentational features such as citations, headings, and non-textual elements (tables, graphs, etc.). Their data on the evolution of the number and type of graphics and formal conventions such as the numbering of tables and figures or the presence of legends, in particular, are useful points of comparison for the present study. The breadth of coverage of their study did not enable them to look in great detail at the interaction between text and graphics, which is a specific focus of the present study, nor did their data focus on medical texts, so the finer-grained analysis presented here should complement the broad sweep of their survey.

The organization of the paper is as follows. I will first describe the number and types of visuals that were found over the whole 200-year period. This will not only bring my previous study (Rowley-Jolivet 2010) which stopped in 1900, up to the present, but it will provide the necessary context for the more specific focus of the study, which is the interaction between the text and the non-textual elements, looking both at the conventions governing the presentation of these elements themselves, and the conventions used for intratextual reference to them.

\section{Study design}

7 I have selected for this study the same British journal as in the earlier investigation, namely The Lancet, a high-impact medical journal currently ranked second out of 150 journals in the general medicine category (Journal Citation Report 2015). It is one of the oldest peer-reviewed medical journals, founded in London in 1823, the date which therefore constitutes the starting-point for this study, by Thomas Wakley, a member of the Royal College of Surgeons and a militant medical reformer (Sprigge 1899). As indicated by the journal's title - a lancet is a surgical instrument - the journal initially focused on surgery. Rapidly, however, the coverage of the journal broadened to include many aspects of medicine, and in addition to the parent journal, published weekly, there are now nine monthly specialty journals - The Lancet Haematology, The Lancet Neurology, The Lancet Oncology, etc. ${ }^{2}$ These were all created very recently, however, and over the two centuries covered by the present study only the parent journal existed; material for the study was therefore collected from the parent journal only.

8 The corpus is based on the same sampling procedure used in the previous study. For each decade between the 1820s and 2015, the first 750 pages of the paper version of the journal were examined at 10-year intervals $-1823-25,1835,1845$, etc. up to 2015 . This gives 20 samples of 750 pages, totaling 15,000 pages. In these 15,000 pages there are 4,788 graphical, or non-textual, elements. All the articles that included graphics were downloaded for analysis. The specific add-ons and affordances of the web-based journal 
were beyond the scope of the present study, and deserve a separate investigation (see e.g., Gross \& Harmon 2016; Perez-Llantada 2013).

\section{Quantitative overview 1823-2015}

In order to contextualize the specific analysis of text-graphics interaction that follows, this section gives an overview of the number and types of graphics over the whole period, and traces their evolution. Figure 1 shows the number of graphics over the whole period.

Fig. 1: Number of graphics 1825-2015 (750 pages per sampling year), in The Lancet

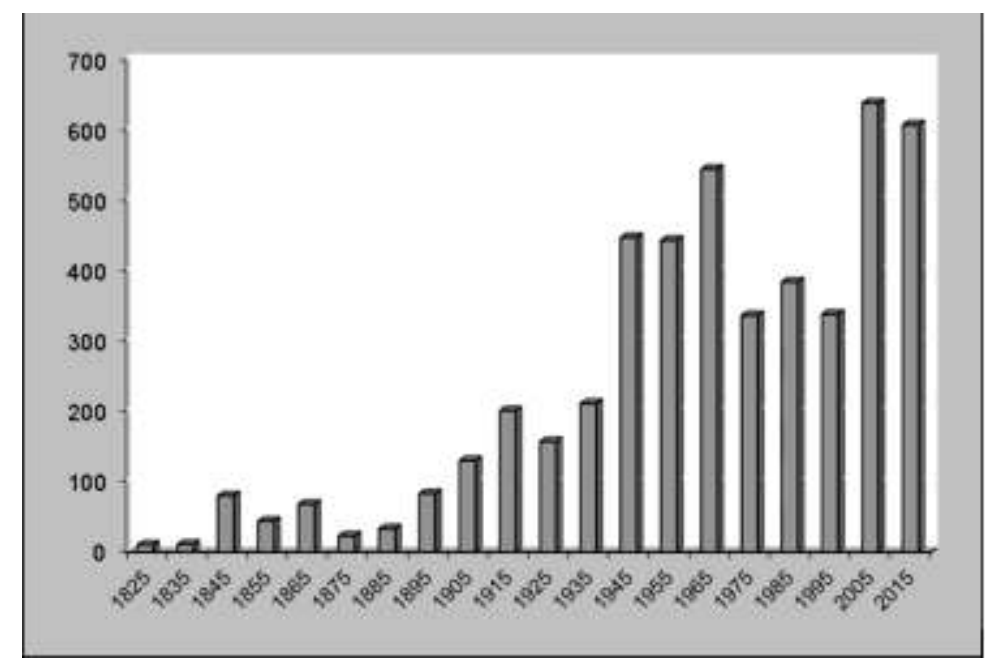

10 As can be seen, there is an enormous difference between the early years and the present time. In the first two decades, 1825 and 1835, there were only 10 graphics per 750 pages, compared to over 600 since 2000 . Indeed, in the whole of the $19^{\text {th }}$ century, there were only 352 graphics, and the number never exceeded 80 per year sampled. The number increased slowly over the century, though with some variations, which can probably be attributed to the sampling procedure: some issues include reports of surgical lectures, a genre which contains a large number of anatomical drawings, whereas in other years $(1855,1875,1885)$, this type of article was absent in the sample, resulting in a much lower number of images.

There are several reasons, both technical and epistemological, for the paucity of graphics in the $19^{\text {th }}$ century. The production of highly detailed anatomical plates, whether by engraving or woodcut, was a time-consuming affair, requiring the skill of an experienced craftsman, and generally reserved for costly books, often long in preparation. For a fledgling journal such as The Lancet, which moreover had to produce issues at regular and frequent intervals, this quality of work was beyond its budget and incompatible with the time constraints on the journal. As a result, the journal could not afford to include many images. The technical breakthrough in the printing process did not come until the invention of photography in the latter years of the century (Ivins 1969). Another reason for the scarcity of graphics of all kinds is the extent of medical knowledge and its methods, which govern what can be understood and 'seen', and hence visualized (Fleck 1979 [1935]). Nineteenth-century medicine was essentially based on narratives of individual case histories or loosely related case collections 
(Atkinson 1992; Taavitsainen et al. 2014), and the burden of the sequential narrative, including any numerical information, was carried by the text, which recounted the case from the beginning to the patient's recovery or death. As each case concerned a single patient, only one visual at most tended to accompany the text. In addition, diagnosis was mainly based on the observation of external phenomena and symptoms; the understanding of internal processes and structures was lacking - X-rays, which were far more informative medically speaking than ordinary photographs, were only discovered in 1895 - and the medical relevance of other sciences such as chemistry, biochemistry, physics, and statistics, with their different and more varied forms of visualization, was not yet perceived.

The years 1905 to 2015 , in contrast, contain 4,436 graphics. The overall trend is that of a marked increase since the beginning of the $20^{\text {th }}$ century: in the first four decades, the number of graphics reached 200 per 750 pages, rising to 650 in 2005, or practically one per page. Figure 1 indicates that the turning point seems to have occurred in the 1940s, when the total number of graphics more than doubled compared to the 1930s. Again, there are some variations, in particular a drop in the number during the decades 1975-1995 compared to the 1950s. It is highly likely that part of the explanation for this decrease is the sampling procedure: as shown in the $19^{\text {th }}$ century, this could result in considerable quantitative differences from one sample to the next. A more exhaustive analysis of all the issues during these three decades would be necessary to check this, however. Notwithstanding, this remarkable increase over the century demonstrates the importance given to visualization in modern medical research and the multimodal resources now used, rather than text alone as in the $19^{\text {th }}$ century. This rise can be attributed in part to technical affordances: since the beginning of the $20^{\text {th }}$ century, the technical obstacles in the printing industry have been overcome, the variety of photographic techniques and the forms of representation used in medicine have progressed enormously. It also reflects, however, a shift towards laboratory-based medicine and the contribution of experimental sciences to the field (analysis of different variables to find significant factors).

Not only the number but also the types of graphics have evolved considerably over the two centuries. To enable comparisons over such a long period, during which nontextual elements underwent a great diversification, broad categories had to be used. The data were therefore grouped into the following four types: drawings, which are figurative representations, either realistic or simplified, of the anatomy or other objects; photographs, which are also figurative representations of phenomena, ranging from simple snapshots to sophisticated microscale imagery; tables, i.e. numerical representations of data; graphs (line graphs, bar charts, etc.), which are constructed and non-figurative. Figure 2 shows the evolution of each category per decade.

In the $19^{\text {th }}$ century, practically the only type of visual in the journal was drawings, accounting for $79 \%$ of the total. These were either technical drawings of apparatus or anatomical drawings of individual cases, both of which had long existed and had developed their specific representational conventions (cf. Vesalius for anatomy, Leonardo da Vinci for both anatomical and technical drawing). Photos (3\% of the total) only began to appear in 1895, and were snapshots of outdoor scenes (the housing of the poor in Budapest) or pictures of individual patients. The occasional graphs ( $4 \%$ of the total) were simple temperature charts, also of individual patients. This confirms the data of Gross et al. (2002), who found no photographs, and only one line graph, in their 
$19^{\text {th }}$-century corpus. The idea that medical phenomena could be represented in nonfigurative ways does not seem to have occurred to the profession in the $19^{\text {th }}$ century. Tables were also absent except for a few in 1845 and 1855 ( $14 \%$ of the total). It is a moot point, though, whether the items I have classified as tables in 1845 would be considered as such nowadays, as will become clear when looking at how they are integrated into the text (section 4.1.2). The first real tables occurred in 1855, which was the period of the Crimean War (1853-1856). It is possible that one of the contributing factors leading medicine to use tables, that can report extended series of data, may have been war: the Crimean War brought together large cohorts of men all suffering from the same complaints (war wounds or infectious diseases such as cholera and dysentery), thereby providing army doctors with the opportunity to go beyond individual case histories and consider groups of patients. However, these tables contain only raw numbers, there are no statistical analyses.

Fig. 2: Evolution of the 4 categories of graphics, 1825-2015, in The Lancet

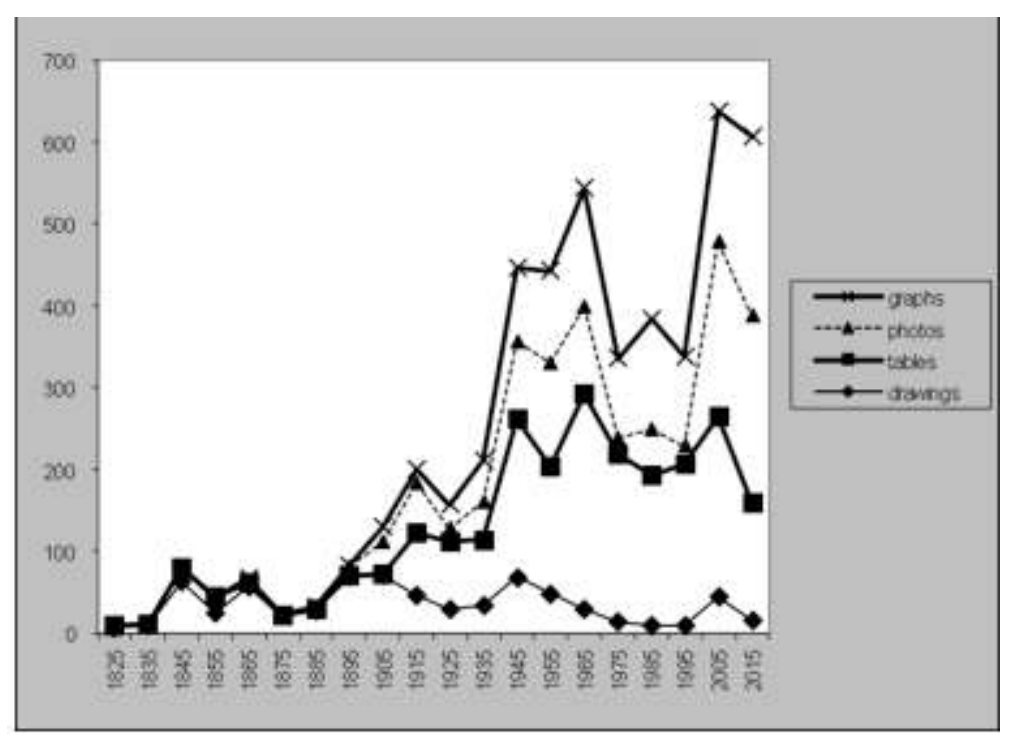

Moving on to the $20^{\text {th }}$ century, and following the line for tables still in Figure 2, one can also observe a very sharp rise in the number of tables in 1915, the period of the First World War, and again in 1945 during World War II, after which the number remains high and rises again in the 1960s. This is the decade when the use of statistics in medicine started to become widespread. Over the whole of the period 1905-2015, tables are the most frequent type of graphic, accounting for $41 \%$ of the total. Drawings have declined in importance since 1900, now numbering no more than they did in 1835, and representing only a very small fraction of the modern total (9\%). Moreover, most of the recent examples are idealized schematic drawings in which all the iconic details have been filtered out. The number of photos has of course increased since 1900, related to the development of photographic techniques: first X-rays and camera photos, then much later ultrasound images, MRI, CAT scans, etc. and represent overall $23 \%$ of the total. This increase is rather erratic, however, with several ups and downs. A striking feature is the enormous increase in photos in the $21^{\text {st }}$ century, to which I return below (section 6). Lastly, graphs, "the reigning monarch of twentieth-century visuals" (Gross et al. 2002: 201) account for $27 \%$ of the total. They have increased fairly regularly ever since 1900 and have now overtaken tables, reflecting the close links that now exist 
between medicine and non-medical sciences such as chemistry, physics, and statistics. While equations are extremely rare in the medical data studied here, the ousting of diagrams by graphs mirrors the evolution observed by Bazerman (1988) in $20^{\text {th }}$-century physics. The marked shifts in the 'graphical mix,' or distribution of the different types of graphics, since the $19^{\text {th }}$ century reflect the evolution of the objects of study and methods used in medicine: only graphs and tables are capable of handling large masses of data in order to compare datasets, reveal trends, and represent change over time or cause and effect relations between variables (Lemke 1998).

\section{The evolution of text-graphics conventions}

How has the co-existence within the same textual space of the verbal text and these various types of graphics evolved over this period of nearly two hundred years? The following sub-sections examine the organizational cues used to relate text and graphics (titles, captions, numbering and intratextual referencing), first in the $19^{\text {th }}$-Nekonata aŭtoro2018-02-10T16:47:00century texts, then in the $20^{\text {th }}$-century articles.

\subsection{The $19^{\text {th }}$ century}

\subsubsection{Titles and captions}

17 Titles were rarely used for graphics in the $19^{\text {th }}$ century in The Lancet: only one fifth of articles gave their graphics a title. This makes the graphic highly dependent on the text, as it cannot be understood without reading the accompanying text; it is not autonomous or self-explanatory. Figure 3 is a typical example from an 1855 article on "A Few Observations on the Wounded from the Crimea."

Fig. 3: Drawing with no title, The Lancet, 1855, pp. 208-9

He then extracted this enormous iron shot, weighing three ounces

and seven drachms.

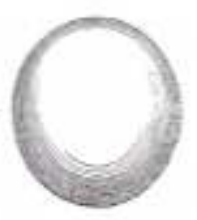

When titles were used, they were often very uninformative: This week; Experiment 1; Number of cases.

Explanatory captions were even rarer in the $19^{\text {th }}$ century: only $10 \%$ of articles included them. As with titles, in order to understand the meaning of the parts of the figure labelled a, b, c, etc., it was necessary to read the surrounding text (Figure 4).

Fig.4: Drawing with no caption, The Lancet, 1845, p.209

I will now proceed to a description of the instrument [...]. The speculum consists of a glass cylinder (Fig 1,a), accurately fitted to an outer one of metal (b,), within which it slides [...]. The edge of the smaller or uterine extremity is carefully rounded into a smooth ring $(\mathrm{c}$,$) ...$ 


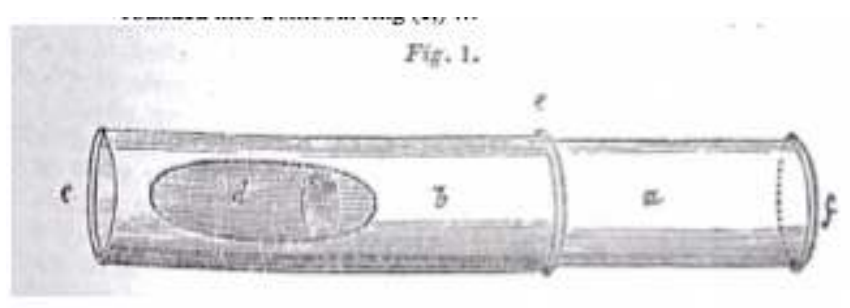

\subsubsection{Numbering of graphics and referencing}

When there was only one graphic in the article, which was the case with half of the $19^{\text {th }}$-century texts, numbering was not felt to be necessary. Moreover, as already mentioned, the majority of $19^{\text {th }}$-century articles recounted individual case histories; there was therefore no ambiguity as to which patient the figure or table referred to, and the title of the article served as title for the graphic. Figure 5, for example, the only visual accompanying the case report, has no title, number, or caption.

Fig. 5: The Lancet, 1845, p. 34. Article entitled "Case of acute fungous disease of the thigh and leg"

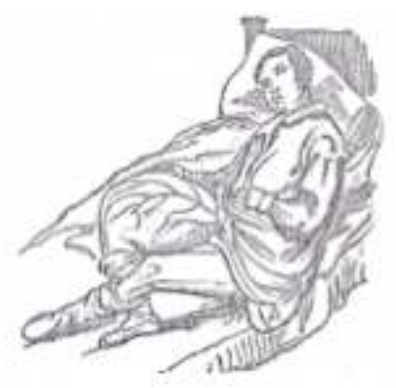

21 In the absence of numbering, the graphics could obviously not be referred to by number in the text, as is customary in modern research articles. This left authors considerable latitude in their choice of referring expressions. Among the various expressions used one finds: the subjoined engraving; the accompanying woodcut represents...; A graphical illustration is given in the appended figure; the tumour of which I enclose a slight sketch; This instrument, as will be seen from the annexed outline; vide sketch. In many cases, integration of the graphic in the text was by simple linear juxtaposition, using cataphoric or anaphoric terms or other deictics to refer to it: the following engraving shows; the apparatus figured above; this is a copy of the engraving; the appearance thus delineated; in the table before you. Authors occasionally made an evaluative comment on the aesthetic quality of the drawing, complimenting the artist who provided the image: the original and beautiful sketch from which the engraving has been taken. Clearly, no conventionalized expressions had yet been established for this referencing function. In some cases, there is no intratextual reference to the graphic at all, the text and graphic are simply juxtaposed within the same textual space.

When the article contains several graphics, however, numbering is clearly very useful if the author wishes to refer to a particular graphic without confusing the reader. This convention was only slowly established however. In the surgical lectures, despite their large numbers of diagrams, no numbering system was used for the drawings up to 1865. The visuals, as in a modern conference presentation (Rowley-Jolivet \& Carter-Thomas 2005), are referred to by inversion (Here is a drawing representing it...; Here is the tourniquet...) or deictics (This is a cast...), by adverbials with present-time reference (as I 
now show you), or by cataphora (the following engraving). No distinction is made between oral delivery and the written article which is a verbatim transcription of the lecture (Figure 6).

Fig. 6: The Lancet, 1845, pp. 3-6. "Lecture on the Operations of Surgery", by R. Liston Esq., F.R.S.

This case is known to surgeons under the name of aneurismal varix. Here is a drawing representing it

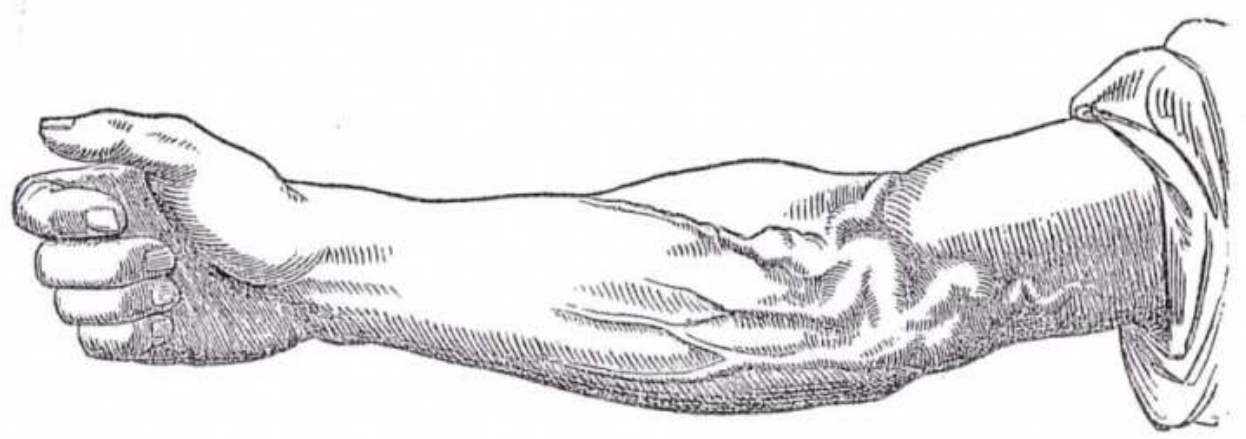

[...] Here is the improved screw tourniquet of Petit.

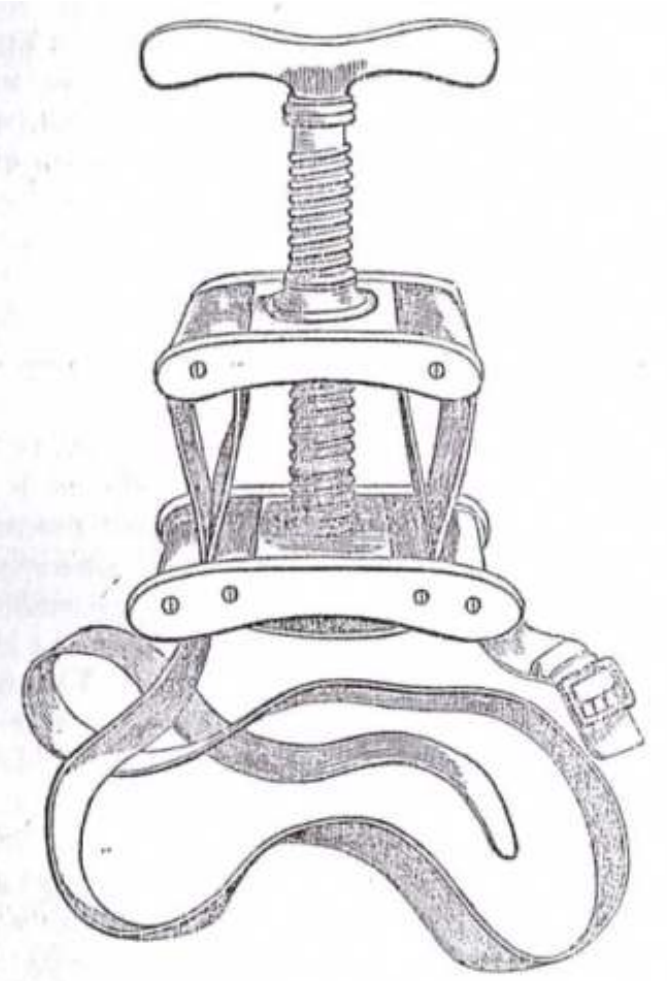

[...] This, for instance is a cast of a most admirably useful hand 

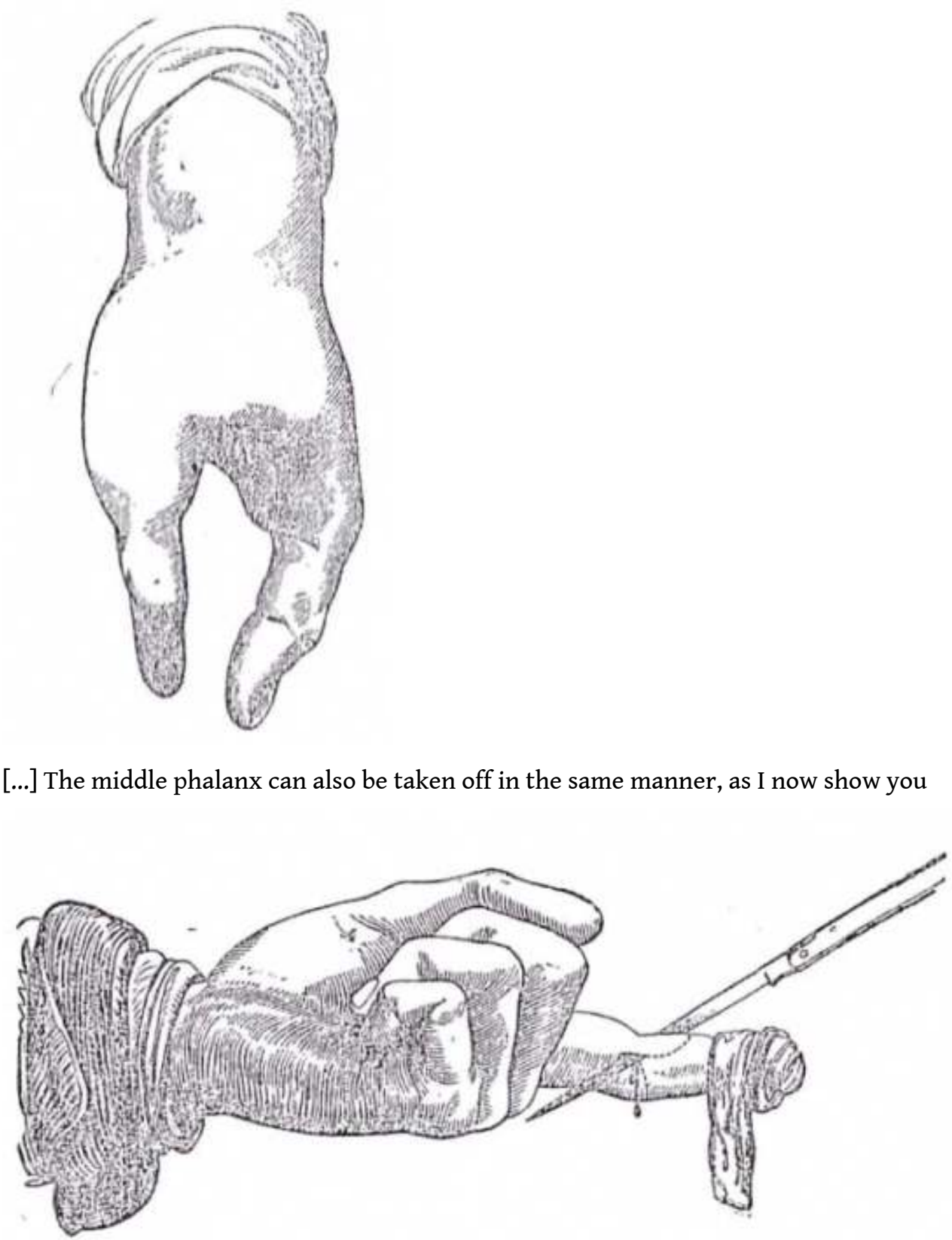

Obviously, this type of presentation has drastic consequences on text-graphics interaction. The drawings had to be placed at exactly the right point in the text, since the sentence immediately preceding the drawing explains the image. Only a linear reading strategy is possible, and the drawings are not self-standing; one has to read the text sequentially to understand what they represent and to grasp their relevance.

By 1865, figure numbers begin to appear sporadically in the surgical lectures, so the figures can be referred to by number in the text. Deictics continue to be used as well, however, which gives the following rather odd combinations to our modern eyes: the largest tumours such as this (Fig. 13) or this (Fig.14); Here are the casts (Fig.11 and 12) and here is the result (Fig.38). This mixture of referring conventions indicates that the 1860 s and 1870 s were a transitional period. From the mid-1880s on, however, in articles containing several images, drawings were systematically numbered, and deictics were 
replaced by references to figure numbers in the text; the conventions were clearly stabilizing.

Only two exceptions to this development were found in the data: drawings of chemical molecules, which are never numbered in the $19^{\text {th }}$ century, as apparently they do not yet seem to be considered as graphics; and some numerical data. Throughout the $19^{\text {th }}$ century and well into the $20^{\text {th }}$ century, much of the numerical data was not presented as tables at all. The text carried a much heavier burden of numerical information than the graphics. Statistics of births and deaths or occurrences of diseases, for example, were given as blocks of text containing a vast quantity of numbers, and not presented as a table or graph, as would be customary nowadays (Figure 7). This type of presentation again enforces a linear reading strategy, and makes it extremely difficult to locate particular items of information or to compare different parameters (disease type, temporal evolution of mortality, age-group of patients, etc.).

Fig. 7: The Lancet, 2 Jan. 1915, "Vital Statistics. Health of EnglishTowns"

The 4882 deaths from all causes were 698 fewer than the number in the previous week, and included 411 which were referred to the principal epidemic diseases, against 429 and 465 in the two preceding weeks. Of these 411 deaths, 175 resulted from measles, 70 from infantile diarrhoeal diseases, 66 from diphtheria, 58 from whooping-cough, 30 from scarlet fever, and 12 from enteric fever, but not one from smallpox. The mean annual death-rate from these diseases was equal to 1.2, against 1.3 per 1000 in the previous week. The deaths attributed to measles, which had been 155,181 , and 210 in the three preceding weeks, fell to 175 , and caused the highest annual death-rates of 1.9 in Birkenhead, 2.6 in Gateshead, 3.4 in Wigan and in Newcastle-on-Tyne, 4.2 in Huddersfield, 4.3 in Merthyr Tydfil, and 7.3 in Grimsby. [...]

Similar to what was observed above in the surgical lectures, in most of the $19^{\text {th }}$ century the text and the tabular data are completely integrated, with the numbers forming part of the syntax of the sentence. An example is shown in Figure 8, where the sentence is part text (the disease [...] had declared itself) and part tabular data (in one child only 203 times). Indeed, apart from the fact that the numbers are arranged in an orderly fashion in columns and rows, it is debatable whether they can be considered as tables stricto sensu. None of the conventions (table number, title, intratextual reference) are yet in place, and again only a linear reading strategy is possible.

Fig. 8: The Lancet, 1845, p. 255. Article entitled “M. Baillarger on hereditary transmission of insanity"

Out of 271 families in which insanity had been transmitted by the mother, the disease, at the period when the observations were taken, had declared itself-

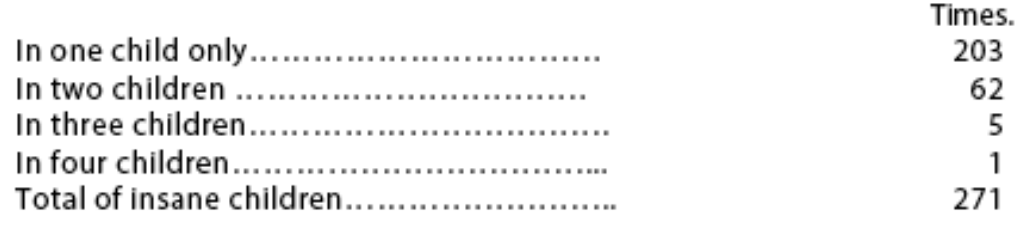

31 Table numbers and table titles started to appear sporadically towards the end of the $19^{\text {th }}$ century, but several presentational systems co-existed side by side until late into the $20^{\text {th }}$ century, often within the same issue of the journal or even within the same 
article. Numerical information continued to be non-autonomous with regard to the text; the statistics in Figure 9, from 1925, are presented without a table number or title, and are syntactically dependent on the preceding text.

Fig. 9: The Lancet, Jan. 3, 1925. Article entitled "Tuberculous meningitis in children"

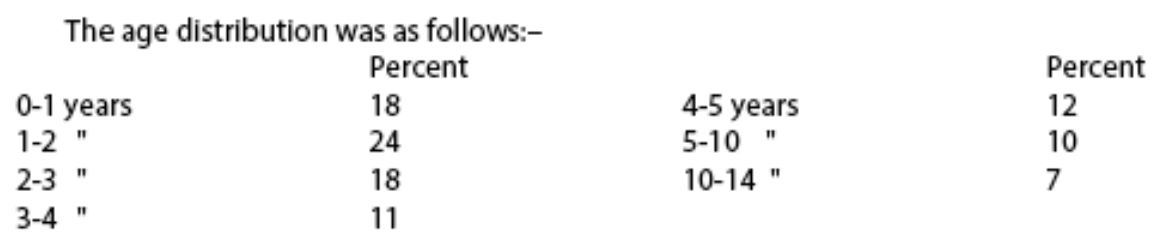

In 1945 one finds a very similar presentation:

\section{METHODS}

An investigation was carried out at West Park Hospital, Epsom, with 8 subjects, as follows:

[data in 9 columns and 4 rows then follow on the page]

And even as late as 1965 , numerical data are not always presented as a numbered table:

The serum-cholesterol levels of the normal males with and without an arcus were: [data in 3 columns and 9 lines then follow]

\subsection{The $20^{\text {th }}$ century}

The evolution of text-graphics conventions in the $20^{\text {th }}$ century can be dealt with more rapidly than in the $19^{\text {th }}$ century, as many of the conventions were fully stabilized from mid-century onwards and ceased to evolve.

\subsubsection{Titles and captions}

Titles for all types of graphics began to be regularly used from 1915 on, and, with some exceptions concerning tabular data noted above, systematically so from 1935 . They also became much more precise and informative, as shown in Figure 10, as medical procedures and analytical categories acquired greater precision.

Fig. 10: Increasing length and precision of titles of graphicsin the $20^{\text {th }}$ century, The Lancet

\begin{tabular}{|l|l|}
\hline Date & Title of the graphic \\
\hline 1925 & TABLE II. (CASE 2) - Blood Counts \\
\hline 1945 & TABLE II-Average Total, Free, and Acetylated Sulphathiozole Levels during the Dosing Period \\
\hline 1975 & $\begin{array}{l}\text { Fig. 3-Incidence of gallbladder disease (\%) in 40-59-year-old female patients with } \\
\text { hyperlipoprotein2emia types Ha and IV compared to that recorded for female subjects of the } \\
\text { same age in reported necropsy series. }{ }^{12-14}\end{array}$ \\
\hline 2005 & $\begin{array}{l}\text { Table 4: Aspirin use, over-the-counter NSAID use, smoking history, and family history of } \\
\text { acute myocardial infarction in 817 randomly selected controls with remote NSAID exposure } \\
\text { or current exposure to celecoxib, ibuprofen, naproxen, or rofecoxib }\end{array}$ \\
\hline
\end{tabular}


A similar evolution is observed in the data concerning captions, or glosses. Their frequency and length gradually increased after 1900 and they started to include statistical information from the 1960s on, thus considerably increasing the autonomy of the graphic in relation to the text (Figure 11). The tables also became longer and more detailed, running to several pages in the case of meta-analyses, and graphs became more complex, as more and more numerical information was transferred from the text to the graphics.

Fig. 11: Increasing length and precision of captions of graphicsin the $20^{\text {th }}$ century, The Lancet

\begin{tabular}{|c|c|}
\hline Date & Caption of the graphic \\
\hline 1935 & $\begin{array}{l}\text { FIG. 2.-Section of lung. Note enlarged cervical glands reaching to the apex of the right lung, } \\
\text { and the thickened pleura. Note also spread into left lower lobe from a roof gland. }\end{array}$ \\
\hline 1955 & $\begin{array}{l}\text { Fig. 8-Perforated duodenal ulcer. Diodone in stomach and small bowel and leaking from } \\
\text { duodenum; capped by air-bubble and spreading as far as } 12^{\text {th }} \text { rib. Note gas under diaphragm, } \\
\text { and left renal calculus. }\end{array}$ \\
\hline 1965 & Prematurity in bacteriuric and non-bacteriuric women is highly significant. $\chi^{2}=11.1, \mathrm{p}<0.001$. \\
\hline 1975 & $\begin{array}{l}\text { Fig. 3-Comparison of the effects of Graves' immunoglobulins on the binding of labelled T.S.H. } \\
\text { to human thyroid membranes (receptor assay) and activation of adenyl cyclase in a similar } \\
\text { membrane preparation. Receptor assay response= \% T.S.H. bound in presence of normal } \\
\text { immunoglobulins minus \% T.S.H. bound in the presence of Graves' immunoglobulins. } \\
\text { Activation of adenyl cyclase= C.A.M.P. produced in the presence of Graves' immunoglobulins } \\
\text { (b-1)/C.A.M.P. produced in presence of normal immunoglobulins (a). }\end{array}$ \\
\hline 1995 & $\begin{array}{l}\text { Figure 3: Mortality in days } \mathbf{0 - 3 5} \text { subdivided by other randomly allocated study } \\
\text { treatments } \\
\text { Comparisons (a), (b), and (c) as in figure } 1 \text {. C=captopril, N=mononitrate, Mg=magnesium: so, } \\
\text { for example, the subgroup assessment of captopril } \mathrm{m} \text { the presence of mononitrate is denoted } \\
\mathrm{C}+\mathrm{N} \text { vs N. Odds ratios (ORs: black squares with areas proportional to the amount of } \\
\text { "statistical information" in each subdivision }{ }^{60} \text { ) comparing the mortality among patients } \\
\text { allocated the study treatment to that among patients allocated the relevant control are } \\
\text { plotted for each of the treatment comparisons, subdivided by the other randomly allocated } \\
\text { study treatments, along with their } 99 \% \text { confidence intervals (Cis: horizontal lines). For each } \\
\text { of the three study treatment comparisons, the overall result and its } 95 \% \mathrm{CI} \text { is represented by } \\
\text { a diamond, with the overall proportional reduction (or increase) and statistical significance } \\
\text { given alongside. Squares or diamonds to the left of the solid vertical line indicate benefit } \\
\text { (significant at } 2 \mathrm{p}<0.01 \text { when the entire horizontal line is to the left of the vertical line and at } \\
2 \mathrm{p}<0.05 \text { when the diamond does not overlap the vertical line). Chi-square tests }{ }^{60} \text { for evidence } \\
\text { of heterogeneity of the sizes of the ORs in the subdivisions are also given. }\end{array}$ \\
\hline 2015 & ver up to half a page in small print \\
\hline
\end{tabular}

\subsubsection{Numbering and intratextual references}

As noted above, numbering of graphics was already the norm by 1900 . The usefulness, or the necessity, of numbering became apparent once articles started to deal with large 
groups of patients, not single case studies, and to analyze different factors. The expressions used to refer to numbered graphics also quickly stabilized around the 1920s, with a limited number of expressions, the ones we use today, namely: as shown in Fig.1; Fig. 1 shows; see Table II; (Fig. 1). The older practice of not numbering continued to exist side by side with the newer convention until the 1950s, however, even in the same article. When the article contained more than one of a given type of graphic (e.g. two or more tables), they would be numbered but when there was only one of a given type (e.g., a single line graph), the latter was often not numbered.

The general trend that emerges from observation of the data in the $20^{\text {th }}$ century is that certain conventions gradually fell into place during the first half of the century, but were not enforced and therefore not applied systematically. Authors retained a certain freedom as to how they presented numerical data (in tabular format or integrated into the text), whether they numbered all the graphics or only some, and how much or what sort of information they chose to include in the captions. Editorial practices were also somewhat variable. No strong conventions yet appeared to govern the layout of the graphics and their positioning within each article: graphics were not systematically framed, the number was sometimes placed above, sometimes below the graphic, and the graphic not necessarily positioned within the section to which it referred. The comment by Gross et al. on their $19^{\text {th }}$-century data could be applied equally well to the first half of the $20^{\text {th }}$ century as far as the medical data studied here are concerned:

while uniformity and convergence are general, there is considerable variation; [...] while there is movement toward the master finding system of the modern scientific article, this movement is not as marked as one might have expected. (Gross et al. 2002: 128)

A turning point occurred, however, during the decade 1955-1965, when the structure of the articles in The Lancet became standardized, with a limited set of organizational headings used to label the different sections. This can probably be related to the publication, in 1964, of the first discipline-specific style manual for medicine, following the growing trend since the beginning of the decade for scholarly societies to codify the presentation of research in their field (Gross et al. 2002: 162). In the 1965 sample, all the research articles conform to the following format: introductory paragraph, Patients and Methods, Results, Discussion, Summary, References. By 1975, the Summary (not yet called Abstract) had moved to the very beginning. With this IMRaD format in place, the graphics began to be properly positioned in the relevant sections (Methods and Results), not haphazardly. It was also in the 1960s that the text-graphics conventions that have been studied here became fully stabilized, as the journal imposed formatting instructions on its authors; all the articles in the 1975 sample comply with them. The rise of personal computers and desktop publishing was obviously a major technological factor in this standardization from the 1970s onwards. Other minor changes to the layout and conventions were introduced in the 1990s: the numbering system for graphics changed from Latin to Arabic numbers, the section on patients and methods started to be printed in a smaller typeface, and information concerning patients to be presented as a table (Patient characteristics), rather than in the text. This is but the latest step in an evolution that started in the early $20^{\text {th }}$ century and that gathered momentum throughout the century, namely the transfer of quantitative or numerical information from the text to the graphics. 


\section{Relation between text-graphics conventions and medical practice and knowledge}

The conventions that have been examined here - titles, captions and numbering of graphics, intratextual referencing - may appear at first glance to be merely superficial, typographical details and thus not worthy of analysis. When looked at from a long-term perspective however, they tell us a great deal about the evolution of medical methods, aims, and knowledge. The semiotic resources and typographical conventions of the medical research article evolved in parallel with the field itself, just as the rhetorical structure and the language used have evolved in response to changes in the practice and communication of science.

In the $19^{\text {th }}$ century, medicine was based on narratives of individual case histories or loose collections of small numbers of cases. The absence of text-graphics conventions reflects this focus on individual case histories: when each article deals only with a single case, usually with a single graphic, there is no real need for titles, numbering or intratextual reference. As the dominant form of visual - figurative diagrams of the anatomy or of instruments - was easily understood and familiar to readers, an explanatory gloss was seldom necessary. This is only part of the explanation, however, because as shown above surgical lectures contained a large number of graphics but still did not use any conventions to label or refer to them until late in the century. I suggest that this is because, like case histories, the surgical procedure was conceived of as a continuous narrative, of which the graphics were an integral part, as shown by their integration into both the spatial layout of the page and the syntax of the sentence. A similar phenomenon was observed with numerical data, which for most of the $19^{\text {th }}$ century were considered an integral part of the textual narrative and so were not marked off from it in proper tables. The content of the table, which would nowadays be presented as its title, was part of the sentence, and the numbers and text formed a single integrated sentence. It was the verbal language (the text) that carried the entire burden of the chronological narrative. The only reading strategy possible in these presentational conditions was to read the document linearly, as one would read a story. So the types of conventions used, or rather not used, corresponded to the dominantly narrative approach to disease of the discipline.

In the $20^{\text {th }}$ century, the progressive establishment of text-graphics conventions paralleled changes in the approach and knowledge of the discipline: the movement from private to public medicine (the growth of hospitals which brought together large numbers of patients), the professionalization of the field and the reconceptualization of medicine on the model of laboratory science from 1900 onwards (Atkinson 1992), meant that medicine evolved from a narrative approach towards experimental procedures, in which separate variables are isolated and tested using randomized controlled trials, laboratory analyses, and statistics of large series and groups of patients. This resulted both in diversifying the types of graphics used in medicine, as it adopted the visualization strategies of experimental sciences, and in increasing enormously the number of graphics needed to report results, which could now no longer be presented as a single linear narrative but were a modular combination of many different variables, sub-groups, and factors. In these conditions, precise conventions such as numbering, titles and intratextual referencing became a necessity to link the text and graphics. The increasing complexity of the graphics themselves and 
the use of statistical measures led to ever-longer explanatory captions. In the early stages, these conventions appear to have developed in a rather sporadic and spontaneous fashion, but once they were explicitly codified by academic journals and professional societies in the second half of the $20^{\text {th }}$ century, they became mandatory and standardized. All these conventions greatly increased the autonomy of the graphics from the text: not only could the graphics be easily located, but understanding their content no longer relied on reading the text. This induces a non-linear reading strategy, in which the graphics acquire increasing importance as a means of supporting claims.

\section{Coda: the $21^{\text {st }}$ century}

Discourse genres never cease to evolve in response to their environment, and while it is doubtless too early to discern what will be the dominant trends in the $21^{\text {st }}$ century, I would like to conclude by touching on two new developments concerning text-graphics conventions that have occurred in the paper version of The Lancet since 2000. The first concerns photos. As pointed out above (Section 3), there was a spectacular rise in the number of photos in 2005 and 2015, which were also the first sampling years to appear in color. This increase is found, however, not in the research articles but in the other parts of the journal such as editorials, comments on current events, or letters. The photos accompanying these texts are snapshots or news photos that illustrate the topic of the article: an editorial on Ebola is accompanied by a news photo of African patients receiving treatment, a comment on the World Health Organization shows a photo of the debating chamber at the WHO, a letter on osteoporosis shows an elderly person with a walking frame, etc. What characterizes these photos is that they display none of the conventions established in the $20^{\text {th }}$ century: no number, title or caption, and no intratextual reference to the photo. Does this mean that we are witnessing a return to the absence of conventions that was characteristic of the early $19^{\text {th }}$ century? Quite the opposite in fact. These photos come from image banks (e.g., Getty Images, Science Photo Library), their function is purely decorative, and the images they show are often stereotypes, reflecting perhaps the influence of web-mediated texts on the journal, where this kind of vignette is very common. It is the absence of all the conventions examined here that very clearly distinguishes them from the medically informative photographs in the research articles of the journal. The text-graphics conventions have become a code that indicates how an image is to be interpreted and what its scientific value is.

The second new feature concerns the compositional layout of the research articles since 2005. In addition to the running text and the graphics, one now finds shaded blocks of text, marked off from the rest of the article by their color. Some are called Panels, others Key Messages, Selection Criteria, or even give verbatim quotes from interviewees. They are not graphics in the traditional sense, but neither are they part of the running text and are often written in a telegraphic style, using bullet points. Only the Panels are numbered and can be referred to by number in the text; the others have none of the text-graphics conventions. They break the text up into small, easily digestible chunks and often resemble PowerPoint slides; for the reader, they are the fast track to certain types of information. Together with the strong autonomy that graphics have now acquired, this makes the $21^{\text {st }}$-century article increasingly modular 
and promotes a 'navigating' reading strategy. This evolution is, of course, particularly in evidence in the online version of the journal, which was beyond the scope of the present study. It will be interesting to follow these developments in the future.

This study is a welcome opportunity to acknowledge the major contribution that David Banks has made to the analysis of specialized discourse by extending its field of investigation to encompass diachronic studies. My interest in diachrony was sparked off by the ERLA symposium $N^{\circ} 7$ that David organized at the University of Brest and subsequently published as Aspects diachroniques du texte de spécialité (Banks, D. [ed.] 2010). The present study is a modest attempt to follow David's lead.

\section{BIBLIOGRAPHY}

ATKINSON, Dwight. 1992. "The evolution of medical research writing from 1735 to 1985: the case of the Edinburgh Medical Journal." Applied Linguistics 13/4, 337-374.

BANKS, David. 2008. The Development of Scientific Writing: Linguistic features and historical context. London: Equinox.

BANKS, David (ed.). 2010. Aspects diachroniques du texte de spécialité. Paris: L'Harmattan.

BAZERMAN, Charles. 1985. "Physicists reading physics: Schema-laden purposes and purpose-laden schema”. Written Communication 2, 233-242.

BAZERMAN, Charles. 1988. Shaping Written Knowledge: The genre and activity of the experimental article in science. Madison: University of Wisconsin Press.

FLECK, Ludwik. 1979 [1935]. Genesis and Development of a Scientific Fact. Chicago: University of Chicago Press.

GROSS, Alan G., Joseph E. HARMON \& Michael REDDY. 2002. Communicating science: The scientific article from the 17th century to the present. Oxford: Oxford University Press.

GROSS, Alan G. \& Joseph E HARMON. 2013. Science from Sight to Insight: How scientists illustrate meaning. Chicago: University of Chicago Press.

GROSS, Alan G. \& Joseph E HARMON. 2016. The Internet Revolution in the Sciences and Humanities. New York: Oxford University Press.

HALLIDAY, Michael A. K. \& James R. MARTIN. 1993. Writing Science. London: Routledge. IVINS, William M. Jr. 1969. Prints and Visual Communication. Cambridge: MIT Press.

Journal Citation Report, Thomson Reuters 2015. <http://thomsonreuters.com/en/productsservices/scholarly-scientific-research/research-management-and-evaluation/journal-citationreports.html>.

LEMKE, Jay. 1998. "Multiplying meaning: Visual and verbal semiotics in scientific text." In MARTIn, J.s R. \& R. VEEL (eds.). Reading Science. London: Routledge, 87-113. 
PEREZ-LLANTADA, Carmen. 2013. "The Article of the future: Strategies for genre stability and change." English for Specific Purposes 32/4, 221-235.

ROWLEY-JOLIVET, Elizabeth. 2010. "The Evolution of medical imagery in the $19^{\text {th }}$ century: The Lancet, 1823-1905.” In BANKS, D. (ed.), Aspects diachroniques du texte de spécialité. Paris: L'Harmattan, 53-74.

ROWLEY-JOLIVET, Elizabeth \& Shirley CARTER-THOMAS. 2005. “Genre awareness and rhetorical appropriacy: Manipulation of information structure by NS and NNS scientists in the international conference setting." English for Specific Purposes 24/1, 41-64.

SPRIGGE, S. Squire. 1899. The Life and times of Thomas Wakley. New York: Longmans Green \& Co.

SWALES, John M. 1990. Genre analysis. Cambridge: Cambridge University Press.

TAAVITSAINen, Irma, Turo hiltunen, Anu LeHto, Ville MARTTILA, Päivi PAHTA, Maura RATIA, Carla SUHR \& Jukka TYRKKÖ. 2014. "Late modern English medical texts 1700-1800: A corpus for analysing eighteenth-century medical English.” ICAME Journal 38/1, 137-153.

\section{NOTES}

1. Recommendations for the Conduct, Reporting, Editing, and Publication of Scholarly Work in Medical Journals <http://www.icmje.org/icmje-recommendations.pdf>.

2. See $<$ http://www.thelancet.com> for further details.

\section{ABSTRACTS}

Present-day medical journal articles contain a large number of typologically varied images and other non-verbal material (tables, statistics). Strong conventions govern the way this graphical material is presented: each item is sequentially numbered, has a title and key or labels, and is linked to the surrounding text by intratextual references. The often lengthy glosses give the graphics an autonomous status in relation to the text. However, the current multimodality of medical research articles and their text-graphics conventions are the result of a long and gradual process; early medical journals contained no tabular data, very few images and an extremely limited visual typology, while the absence of titles and labels, intratextual references and glosses meant that only a linear reading strategy was possible. This study traces the gradual emergence of these conventions since the founding of the British journal The Lancet in 1823 up to the present day and proposes some explanations for the changes observed.

Les articles de recherche actuels en médecine contiennent un grand nombre d'images de divers types ainsi que d'autres éléments non verbaux (tableaux, statistiques). La présentation de tous ces éléments est régie par des conventions fortes : chaque élément est numéroté, comporte un titre et une légende, et il est relié au texte par des références intratextuelles. Les légendes, souvent très détaillées, confèrent à ces éléments une grande autonomie par rapport au texte. Cependant, la multimodalité actuelle des articles de recherche en médecine, et les conventions qui régissent l'interaction entre texte et éléments non verbaux, résultent d'un long processus : les premiers articles publiés dans les revues médicales se caractérisent par l'absence de tableaux, 
très peu d'images et une typologie visuelle très restreinte. L'absence de titres, de légendes, et de références intratextuelles imposaient une stratégie linéaire de lecture. L'objectif de la présente étude est de retracer l'émergence de ces conventions depuis 1823, date de la parution de la première revue médicale anglaise, The Lancet, jusqu'à nos jours, et de proposer des explications pour les évolutions constatées.

\section{INDEX}

Mots-clés: anglais médical, article de recherche, diachronie en anglais de spécialité, interaction texte-image

Keywords: diachronic ESP, medical English, research article, text-graphics interaction

\section{AUTHOR}

\section{ELIZABETH ROWLEY-JOLIVET}

Elizabeth Rowley-Jolivet is a research member of the Laboratoire Ligérien de Linguistique at the University of Orleans, France. Her research interests cover multimodality in spoken and written scientific discourse, the epistemology of science, genre analysis of academic discourse, webmediated genres, and English as a Lingua Franca in academic settings. She has published in several international journals, compiled or contributed to several corpora in ESP and ELF, and coedited books in these areas. elizabeth.jolivet@univ-orleans.fr 